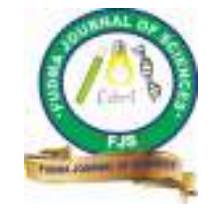

FUDMA Journal of Sciences (FJS)

ISSN online: $2616-1370$

ISSN print: 2645 - 2944

Vol. 4 No. 2, June, 2020, pp $190-196$

DOI: https://doi.org/10.33003/fjs-2020-0402-210

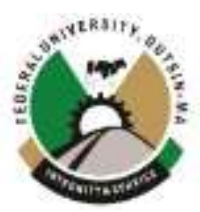

\title{
PURIFICATION OF $\beta$-GLUCOSIDASE PRODUCED FROM Trichoderma viride USING COW DUNG AS CARBON SOURCE
}

\author{
${ }^{{ }^{* 1}}$ Tyohemba, S. T., ${ }^{2}$ Aliyu, S., ${ }^{1}$ Ndukwe, N. N., ${ }^{1}$ Memi, G. G. and ${ }^{3}$ Edem, U. O. \\ ${ }^{1}$ Department of Biological Sciences, Federal University Kashere, Gombe State, Nigeria. \\ ${ }^{2}$ Department of Biochemistry, Ahmadu Bello University, Zaria, Kaduna State, Nigeria. \\ ${ }^{3}$ National Research Institute for Chemical Technology, Zaria, Kaduna State, Nigeria. \\ ${ }^{*}$ Corresponding author's email: terhide27@ gmail.com. Tel.:+2347013309635
}

\begin{abstract}
$\beta$-glucosidases have characteristics of biotechnological interest and have thus become important industrial enzymes.In this study, $\beta$-glucosidase produced by Trichoderma viride from cow dung was subjected to a three step purification process involving ammonium sulphate precipitation, gel filtration by Sephadex G-100 and ion exchange chromatography by DEAE-Sephadex A-25. The elution profile on Sephadex G-100 resulted in a single broad peak (fractions 9-21) which had a yield of 3.7\% and a purification fold of 4.29 with a specific activity of $25.70 \mu \mathrm{mol} / \mathrm{min} / \mathrm{mg}$ proteins while the elution profile on DEAE-Sephadex A-25 resulted in a single broad peak (fraction 8-14) which had a yield of $2.76 \%$ and a purification fold of 22.14 with a specific activity of $132.41 \mu \mathrm{mol} / \mathrm{min} / \mathrm{mg}$ of protein. The purified enzyme was obtained as a single band and had a molecular mass of $51.8 \mathrm{kDa}$ on SDS-PAGE. This results provide support for further studies of this enzyme towards revealing its potential biotechnological applications.
\end{abstract}

Keywords: $\beta$-glucosidase, Purification, Cow dung, Enzyme activity Trichoderma viride.

\section{INTRODUCTION}

$\beta$-glucosidase (EC 3.2.1.21) is a component of cellulase complex and has a synergistic action on the degradation of cellulose with endoglucanase (EC 3.2.1.4) and exoglucanase (EC 3.2.1.91) (Del pozo et al., 2012). The highest proportion of municipal and plant wastes are made up of celluloses and represent a major source of raw materials and renewable energy (Jatinder et al.,2007). Some of the industrial applications that employ the use $\beta$-glucosidase include biofuel production, cassava detoxification, food and feed processing (Obilie et al., 2004; Coughlan, 1985) Cellulases are currently the third largest industrial enzymes being sold at commercial level worldwide. The global enzyme market was expected to have reached $\$ 4.4$ billion by 2015 and the highest sales of enzymes occurred in the leather market, followed by the bioethanol market (Binod et al., 2013). Due to the expanding applications of cellulases in bioenergy and other sectors, the market of cellulases is expected to expand to become the largest in the nearest future. $\beta$ glucosidase can be produced from bacteria, fungi, plants and animals (Joo et al.,2010; Han and Chen, 2008). Many fungal strains secrete higher amounts of $\beta$-glucosidase with Trichoderma sp. being the most potent. Although, the cellulolytic enzymes from Trichoderma reesei have been investigated thoroughly (Saloheimo et al.,1997; Arja et $a l ., 2004)$, the quantity of $\beta$-glucosidase secreted by $T$. reesei is not a enough for effective conversion of cellulose to glucose (Sorensen et al., 2013). Other filamentous fungi that have been shown to produce $\beta$-glucosidase include Aspergillus oryzae, A. niger, A. carbonarius, A. fumigatus, A. saccharolyticus, Penicillium purpurogenum, Trichoderma koningi, T. viride and Fusarium solani (Brumbauer et al., 2000; Tsao et al., 2000; Dhake and Patil, 2005; Zhang et al., 2007; Irshad et al., 2013; Sorensen et al., 2013).

The ability of fungi to grow on surfaces of various substrates and penetrate into their inter-particle spaces makes them one of the best adapted species in the use of agro-residues (ViniegraGonzalez and Favela-Torres, 2006). Several lignocellulosic substrates, such as sugarcane bagasse, wheat straw, rice straw, saw dust, corn cobs, corn stover, banana peels, rice husk and orange peel (Iqbal et al.,2011a; Iqbal et al.,2011b; Irshad et al.,2013) have been utilized as potential substrates for $\beta$ glucosidase production. The bioprocessing of these low cost feedstocks can help reduce environmental pollution as well as production cost of raw materials.

Cow dung is one of the most abundant and unexploited resource for $\beta$-glucosidase production. It contains $35.4 \%$ cellulose, 32.6 $\%$ hemicelluloses, $13.3 \%$ ash, and $1.4 \%$ nitrogen (Misra et al., 2003). The nitrogen and carbon ratio in cow dung is an indication that it could be a promising feedstock for culturing microorganisms (Adegunloye et al., 2007). This study was aimed at purifying $\beta$-glucosidase produced by Trichoderma viride. 


\section{MATERIALS AND METHODS}

\section{Sample collection}

Cow dung was obtained from Faculty of Veterinary Medicine, Ahmadu Bello University, Zaria, Nigeria. It was air-dried for seven (7) days at room temperature and finely ground using mortar and pestle to have a uniform particle size of $1 \mathrm{~mm}$. The ground cow dung was stored in air tight containers before further use. Trichoderma viride was obtained from the culture stock of Department of Microbiology, Ahmadu Bello University, Zaria.

Microbial inoculum preparation.

Seven-day-old potato dextrose agar slant containing Trichoderma viride was used to prepare the inoculum culture. In this study, the spore suspension was prepared by aseptic addition of $10 \mathrm{ml}$ of sterile distilled water into the culture slant. Conidial clumps were broken using a sterile glass rod. The tube was shaken to make homogenous mixture of the suspension which was then counted using a hemocytometer, and the inoculum concentration of $1 \times 10^{6}$ spores per $\mathrm{ml}$ was prepared as described by Irfan et al. (2014).

\section{$\beta$-glucosidase Production by Solid State Fermentation}

Eight grams $(8 \mathrm{~g})$ of the substrate (cow dung) was transferred into a $250-\mathrm{mL}$ Erlenmeyer flask and the moisture content was maintained at $60 \%(\mathrm{w} / \mathrm{v})$. The content was mixed thoroughly and autoclaved at $121{ }^{\circ} \mathrm{C}$ for 15 mins. After cooling the flask to room temperature, it was inoculated with $5 \%(\mathrm{w} / \mathrm{v})$ of $T$. viride inoculum under aseptic conditions. The culture was then incubated at $30{ }^{\circ} \mathrm{C}$ for 7 days, and after incubation, $80 \mathrm{ml}$ of distilled water was added to the fermented substrate. This was placed in an orbital shaker at $150 \mathrm{rpm}$ for $30 \mathrm{~min}$. for enzyme extraction. After this, the mixture was filtered using Muslin cloth and centrifuged at $10,000 \mathrm{x}$ g for $20 \mathrm{~min}$. The supernatant obtained was used to assay for the activity of enzyme (Irfan et al, 2014).

\section{$\beta$-glucosidase assay}

The enzyme activity was assayed using the method of Tomaz and Roche (2002). The reaction mixture consisted of $0.1 \mathrm{ml}$ enzyme solution, $0.2 \mathrm{ml}$ substrate $(1 \%$ Salicin) and $0.1 \mathrm{ml}$ citrate buffer ( $\mathrm{pH} 4.8$ ). The tubes containing the mixture were incubated at $50{ }^{\circ} \mathrm{C}$ for $30 \mathrm{~min}$. Thereafter, $3 \mathrm{ml}$ of Dinitrosalicylic acid (DNS) was added into each tube and then transferred into a water bath set at $100{ }^{\circ} \mathrm{C}$ for $15 \mathrm{~min}$. The tubes were allowed to cool and absorbance was taken at $540 \mathrm{~nm}$. One unit of enzyme activity (U) was defined as the amount of the enzyme that liberated $1 \mu \mathrm{mol}$ of glucose from the substrate per minute under standard assay conditions. The results are expressed in terms of units per gram of cow dung $(\mathrm{U} / \mathrm{g})$.

\section{Protein assay}

Protein content of the culture supernatant was assayed according to Bradford method (1976) using bovine serum albumin (BSA) as a standard. To $0.25 \mathrm{ml}$ of culture supernatant, $1.35 \mathrm{ml}$ of distilled water was added and mixed; then $0.4 \mathrm{ml}$ of Bradford reagent was added to the reaction mixture and incubated for 30 min at room temperature. The absorbance was read at $595 \mathrm{~nm}$ and the amount of protein in the sample was determined with reference to the protein standard curve.

\section{Partial purification of extracellular $\beta$-glucosidase}

\section{Ammonium sulphate precipitation}

Crude enzyme supernatant was precipitated by adding ammonium sulphate at $90 \%$ saturation level. After addition, the enzyme solution was left for $24 \mathrm{~h}$ at $4{ }^{\circ} \mathrm{C}$ and the protein precipitate was collected by centrifugation at $8000 \mathrm{xg}$ for $15 \mathrm{~min}$ at $4{ }^{\circ} \mathrm{C}$ and then resuspended in $20 \mathrm{ml}$ of $0.05 \mathrm{M}$ citrate buffer $(\mathrm{pH} 4.8)$ to get the concentrated enzyme suspension (Swangkeaw et al., 2009).

\section{Gel filtration chromatography}

The concentrated enzyme sample was purified on sephadex G100 (Sigma, USA) column $(1.5 \times 50 \mathrm{~cm})$. The sephadex column was equilibrated with $0.05 \mathrm{M}$ citrate buffer, $\mathrm{pH} 4.8$. The enzyme sample was loaded on the sephadex G-100 and eluted with the same buffer. The flow rate was maintained at $0.5 \mathrm{ml} / \mathrm{min}$. Up to 28 fractions were collected each of $2 \mathrm{~mL}$ and both the enzyme activity and protein concentration were determined for each fraction. The fractions with higher enzyme activity were pooled together for the next purification step (Bai et al., 2013).

\section{Ion exchange chromatography}

The $\beta$-glucosidase active fraction obtained following the Gel filteration was loaded onto a DEAE-Sephadex A-25 column $(1.5 \mathrm{~cm} \times 50 \mathrm{~cm})$ pre-equilibrated with phosphate buffer $(0.05$ $\mathrm{M}, \mathrm{pH}$ 7.0). Elution of column was carried out using stepwise gradient ranging from 0.05 to $1.0 \mathrm{M}$ of sodium chloride $(\mathrm{NaCl})$ in $0.05 \mathrm{M}$ citrate phosphate buffer $(\mathrm{pH} 7.0)$ with a flow rate of $0.5 \mathrm{ml} / \mathrm{min}$. $\beta$-glucosidase activity and protein concentration were determined by standard assay procedure (Bai et al., 2013).

\section{SDS-PAGE for molecular weight determination}

Sodium dodecyl sulphate polyacrylamide gel electrophoresis (SDS-PAGE) was performed on a $12 \%$ separating and $5 \%$ stacking gel according to the method of Laemmli (1970) to determine the molecular weight of partially purified $\beta$ glucosidase. To $100 \mu \mathrm{L}$ of protein sample, $50 \mu \mathrm{L}$ of sample buffer $(0.05 \%$ bromophenol blue, $5 \% \beta$-mercaptoethanol, 10 $\%$ glycerol, and $1 \%$ SDS in $0.25 \mathrm{M}$ Tris- $\mathrm{HCl}$ buffer; $\mathrm{pH}$ 6.8) was added and boiled in a water bath for $5 \mathrm{~min}$, cooled at room temperature and loaded onto the gel. Electrophoresis was performed at room temperature for $2.5 \mathrm{~h}$ at 100 volt. Thereafter, the gel was placed in isopropanol fixing solution $[10 \%(\mathrm{v} / \mathrm{v})$ acetic acid, $25 \%$ (v/v) isopropanol, $65 \%$ double distilled $\mathrm{H}_{2} \mathrm{O}$ ] 
for 20 minutes followed by washing with three changes of distilled water at every $30 \mathrm{~min}$ interval. The protein bands were visualized by staining with Coomassie Brilliant Blue G-250 and destaining was done again with distilled water which was kept overnight at room temperature. The molecular weight of the purified $\beta$-glucosidase was determined in comparison with standard protein marker (12- $150 \mathrm{kDa}$; Sigma, USA).

\section{Partial purification of $\beta$-glucosidase} Purification table

The results of the partial purification of $\beta$-glucosidase from $T$. viride was presented in Table 1 . Crude $\beta$-glucosidase had a specific activity of $5.98 \mu \mathrm{mol} / \mathrm{min} / \mathrm{mg}$ protein, but when subjected to three purification steps, the specific enzyme activity increased to $132.41 \mu \mathrm{mol} / \mathrm{min} / \mathrm{mg}$ protein with a total yield of $2.76 \%$ and purification fold of 22.14 as shown in Table 1.

\section{RESULTS AND DISCUSSION}

Table 1: Purification Table of partially purified $\beta$-glucosidase from T.viride

\begin{tabular}{|c|c|c|c|c|c|}
\hline Purification Step & $\begin{array}{c}\text { Total enzyme } \\
\text { Activity } \\
(\mu \mathrm{mol} / \mathrm{min})\end{array}$ & $\begin{array}{c}\text { Total Protein } \\
\text { Concentration }(\mathrm{mg})\end{array}$ & $\begin{array}{c}\text { Specific } \\
\text { Activity } \\
(\mu \mathrm{mol} / \mathrm{min} / \mathrm{m} \\
\text { g protein })\end{array}$ & Purification fold & Yield (\%) \\
\hline Crude enzyme & 277.80 & 46.40 & 5.98 & 1.00 & 100 \\
\hline$\left(\mathrm{NH}_{4}\right)_{2} \mathrm{SO}_{4}$ precipitation & 119.50 & 15.92 & 7.50 & 1.25 & 43.01 \\
\hline Sephadex G-100 & 10.28 & 0.40 & 25.70 & 4.29 & 3.70 \\
\hline DEAE Sephadex A-25 & 7.68 & 0.06 & 132.41 & 22.14 & 2.76 \\
\hline
\end{tabular}

\section{Gel filtration on Sephadex G-100}

The elution profile (Figure 1) resulted in single broad peak (fractions 9-21) which had a yield of 3.7\% and a purification fold of 4.29 with a specific activity of $25.70 \mu \mathrm{mol} / \mathrm{min} / \mathrm{mg}$ protein. These active fractions $(9-21)$ were pooled together for the next purification step. 


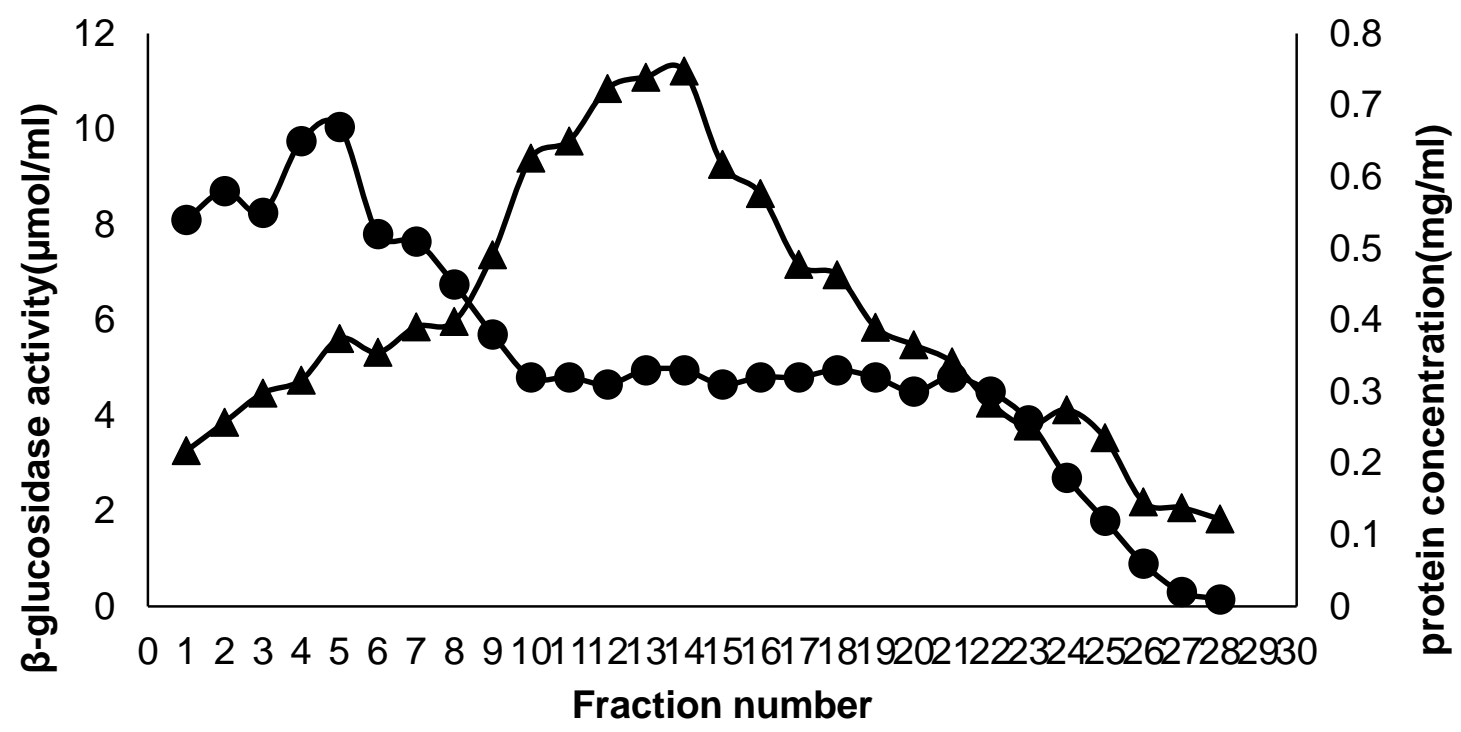

$\rightarrow$ activity $\rightarrow$ - protein concentration

Figure 1: Elution Profile of $\beta$-glucosidase from T.viride on Sephadex G-100 Column Chromatography (1.5x50cm).The elution profile of gel filtration on sephadex G-100 showed highest $\beta$-glucosidase activity at fraction 14 with an enzyme activity of 11.22 $\mu \mathrm{mol} / \mathrm{min}$ and protein concentration of $0.33 \mathrm{mg}$.

Ion Exchange Chromatography on DEAE-Sephadex A-25

Figure 2. Showed the elution profile of $\beta$-glucosidase on DEAE sephadex A-25 which resulted in a single broad peak (fraction 814). This peak had a yield of $2.76 \%$ and a purification fold of 22.14 with a specific activity of $132.41 \mu \mathrm{mol} / \mathrm{min} / \mathrm{mg}$ of $\mathrm{protein}$. The seven active fractions $(8-14)$ that showed highest $\beta$-glucosidase activity were pooled and stored at $4{ }^{0} \mathrm{C}$ for further use. From the result of this study, there was an increase in the purification fold from 1 to 22.14 (Table 1), while the specific activity also increased from $5.84 \mu \mathrm{mol} / \mathrm{min} / \mathrm{mg}$ to $132.41 \mu \mathrm{mol} / \mathrm{min} / \mathrm{mg}$. The increased purification fold and specific activity of the crude $\beta$-glucosidase after the three purification stages could be as a result of removal of other unwanted interacting components of the enzyme (Hiol et al.,2000). Auta et al. (2016) reported 2.58 purification fold with $16.67 \%$ yield of $\beta$-glucosidase form Aspergillus nidulans AN 2227; while Kaur et al. (2007) reported 4.06 purification fold with $15.89 \%$ yield of $\beta$-glucosidase isolated from Melanocarpus sp MTCC 3922. Also, Chauve et al. (2010) purified $\beta$-glucosidase from two fungal species with a yield of $95 \%$ and purification fold of 53 using anion exchange chromatography. Irshad et al. (2013) purified an extracellular $\beta$-glucosidase from $T$. viride by ammonium sulphate precipitation and Sephadex G-100 gel filtration chromatography and the enzyme was purified 5.1 fold with a yield of $8.1 \%$. 


\section{$\rightarrow$ activity $\rightarrow$-protein concentration}

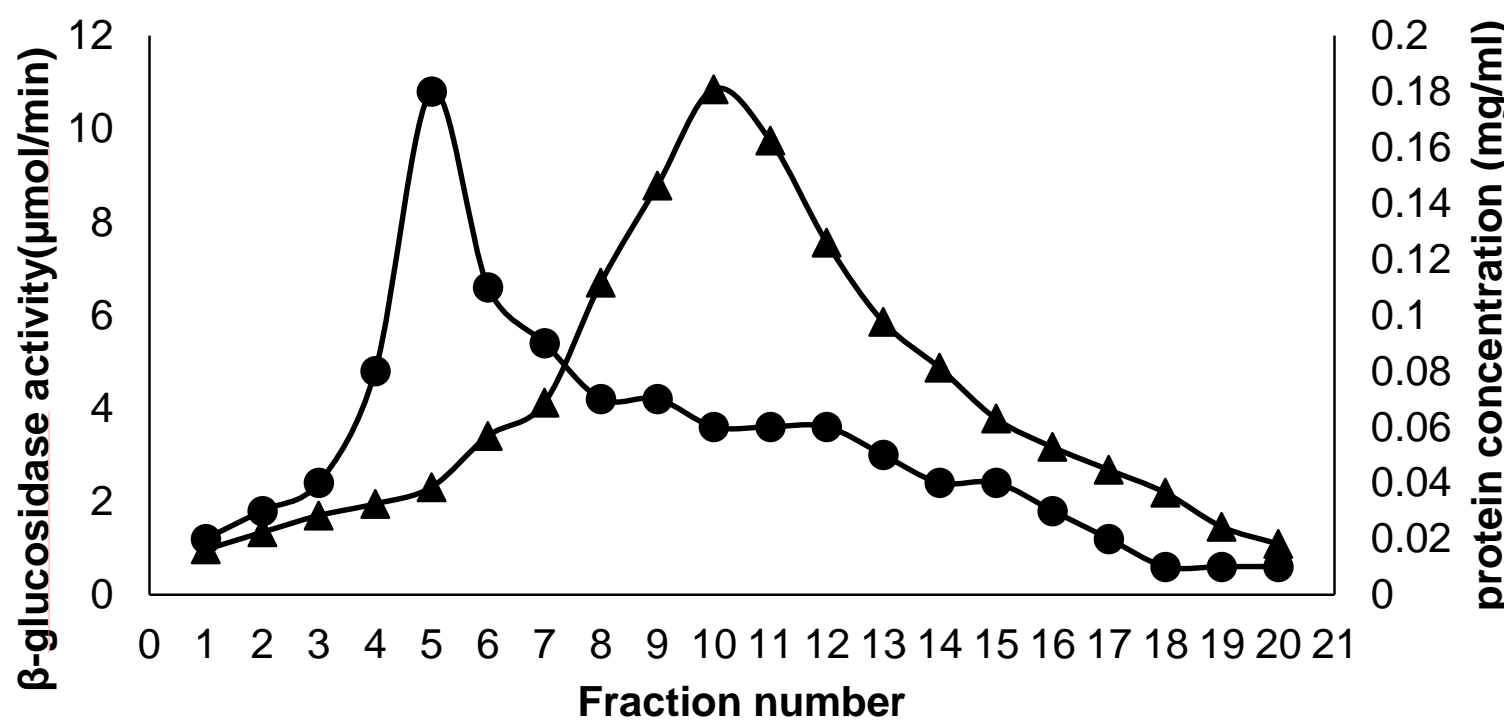

Figure 2: Elution Profile of $\beta$-glucosidase from T. viride on DEAE Sephadex A - 25 Column Chromatography $(1.5 \times 50 \mathrm{~cm})$.

Determination of molecular weight of $\beta$-glucosidase by SDS-PAGE

Figure 3 indicates that the purified $\beta$-glucosidase had a single band corresponding to $51.8 \mathrm{kDa}$ on SDS-PAGE relative to the standard molecular weight markers suggesting the enzyme is a monomer. Irshad et al. (2013) reported that $\beta$-glucosidase from $T$. viride was purified to homogeneity by SDS-PAGE with a molecular mass of $68 \mathrm{kDa}$; while Saleem et al. (2009) reported the purification of $\beta$-glucosidase from Bacillus sp. with a molecular mass of $46 \mathrm{kDa}$ as determined by SDS-PAGE. The difference in the molecular weight of $\beta$-glucosidase in different organisms could be due to the presence of multiple forms and glycosylation of the enzyme (Narasimha et al., 2016).

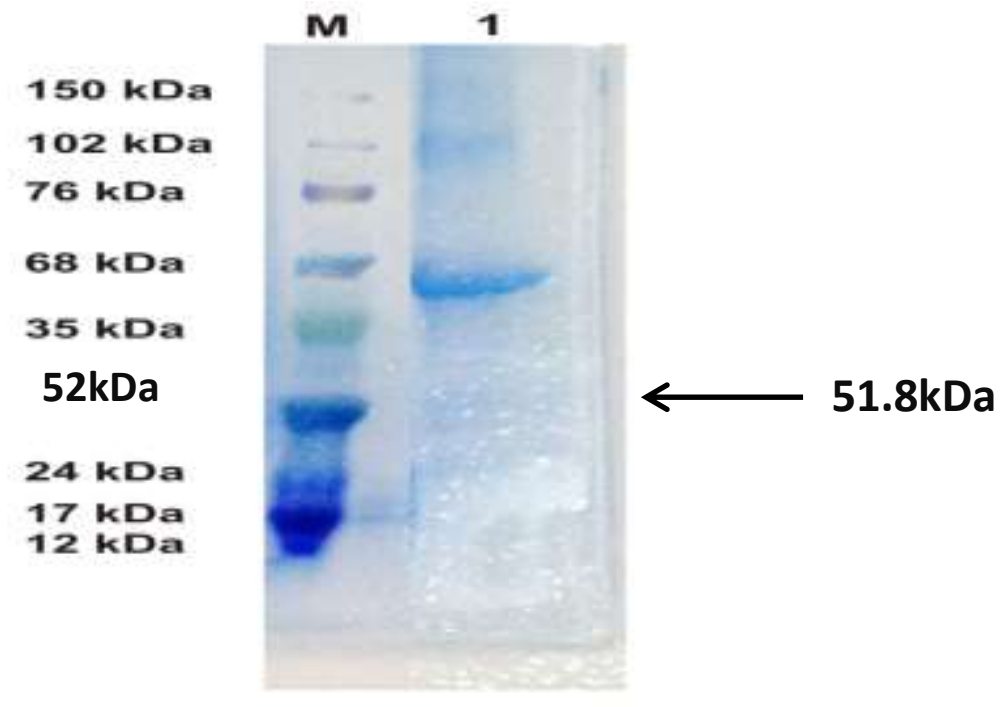

Figure 3: SDS-PAGE of partially purified $\beta$-glucosidase from T. viride; Lane M, Standard Protein Markers with molecular weights in $\mathrm{kDa}$; Lane 1 , purified $\beta$-glucosidase 


\section{CONCLUSION}

The produced $\beta$-glucosidase by Trichoderma viride was partially purified 22 fold using a 3 step purification process (Ammonium Sulphate Precipitation; Gel-filtration and Ion Exchange chromatography) and had a molecular weight of 51.8 $\mathrm{kDa}$ based on SDS-PAGE

\section{REFERENCES}

Adegunloye, D.V., Adetuyi, F.C., Akinyosoye, F.A., and Doyeni, M.O., (2007). Microbial analysis of compost using cowdung as booster. Pakistan Journal of Nutrition, 6: 506-510.

Arja, M., John, L., Vesa, J., and Raija, L. (2004). Three cellulases from Melanocarpus albomyces for textile treatment at neutral pH. Enzyme Microbiology and Technology, 34: 332-341.

Auta, R., Wusu, A. D., Radeeka, I., and Hooley, P. (2016). Expression and characterization of recombinant $\beta$-glucosidases from Aspergillue nidulans. AN2227. Science World Journal, 11(2):1597-6343.

Bai, H., Wang, H., Sun, J., Irfan, M., Han, M., Huang, Y., Han, X. and Yang, Q. (2013). Production, purification and characterization of novel $\beta$-glucosidase from newly isolated Penicillium Simplicissimum H-11 in submerged fermentation. EXCLI Journal, 12: 528 - 540.

Binod, P., Palkhiwala, P., Gaikaiwari, R., Nampoothiri, K.M., Duggal, A., Dey, K., and Pandey, A. (2013). Industrial enzymes - present status and future perspectives. India Journal of Science Industrial Resources, 72: 271-286.

Bradford, M.M. (1976). A rapid and sensitive method for the quantitation of microgram quantities of protein utilizing the principle of protein-dye binding. Analytical Biochemistry, 72: 248 - 254.

Brumbauer, A., Johansson, G., Reczey, K. (2000). Study heterogeneity of $\beta$-glucosidase from Aspergillus species by using counter current distribution. Journal of Chromatography B: Biomedical Science Applied, 74:247 -254.

Chauve, M., Mathis, H., Huc, D., Casanave, D., Monot, F., and Ferreira, N.L. (2010). Comparative kinetic analysis of two fungal $\beta$-glucosidases. Biotechnology Biofuels, 3:3.

Coughlan, M.P. (1985). The properties of fungal and bacterial cellulases with comment on their production and application. Biotechnology and Genetic Engineering Reviews, 3(1): 39-110.

Del Pozo, M.V., Fernandez-Arrojo, L., Gil-Martinez, J., Montesinos, A., Chernicova, T.N., Nechitaylo, T.Y., Waliszek, A., Tortajada, M., Rojas, A., Huws, S.A., Golyshina, O.V., Newbold, C.J., Polaina, J., Ferre, M. and Golyshin, P.N. (2012). Microbial $\beta$-glucosidases from cow rumen metagenome enhance the saccharification of lignocellulose in combination with commercial cellulase cocktail. Biotechnology for Biofuels, 5(3): $1-13$.

Dhake, A. and Patil, M. (2005) Production of B-glucosidase by Penicillium purpurogenum. Brazilian Journal of Microbiology, 36(2): 170-176.

Han, Y.J. and Chen, H.Z. (2008). Characterization of $\beta$-glucosidase from corn stover and its application in simultaneous saccharification and fermentation. Bioresources Technology, 99: 6081-6087.

Hiol, A., Jonzo, M. D., Rugani, N., Druet, D., Sarda L., and Corneau L.C. (2000). Purification and characterization of an Extracellular Lipase from a thermophilic Rhizopus oryzae strain isolated from Palm fruit. Enzyme and Microbial Technology, 26(5-6): 421-430.

Iqbal, H. M. N., Ahmed, I., Zia, M. A., and Irfan, M. (2011a). Purification and characterization of the kinetic parameters of cellulase produced from wheat straw by Trichoderma viride under SSF and its detergent compatibility. Advances in Bioscience and Biotechnology, 2:149-156.

Iqbal, H.M.N., Asgher, M. and Bhatti, H.N. (2011b). Optimization of Physical and Nutritional Factors for Synthesis of lignin degrading enzymes by a Novel Strain of Trametes versicolor. BioResources, 6: 1273-87.

Irfan, M., Nadeem, M., and Syed Q. (2014). One-factor-at-atime (OFAT) optimization of xylanase production from Trichoderma viride-IR05 in solid-state fermentation. Journal of Radiation Research and Applied Sciences, 7: 317-326.

Irshad M., Anwar Z., Ramzan, M., Mahmood, Z., and Nawaz, H. (2013). Characterization of purified $\beta$-glucosidase produced from Trichoderma viride through bio-processing of orange peel waste. Advances in Bioscience and Biotechnology, 4: 941-944

Jatinder, K., Bhupinder, S., Badhan, A., Ghatora, S., and Harvinder, S. (2007). Purification and characterization of $\beta$ glucosidase from Melanocarpus sp. MTCC 3922. Journal of Biotechnology, 10: 260-270.

Joo, A.R., Jeya, M., Lee, K.M., Lee, K.M, Moon, H.J., Kim, Y.S., and Lee, J.K. (2010). Production and characterization of $\beta-1,4$-glucosidase from a strain of Penicillium pinophilum. Journal Process Biochemistry, 45: 851-858.

Kaur, J., Chadha, B.S., Kumar, B.A., Kaur, G., and Saini, H.S.(2007): Purification and characterization of B-glucosidase from Melanocarpus sp. MTCC 3922. Electronic Journal of Biotechnology, 10(2):260-270.

Laemmli, U. K. (1970) Cleavage of structural proteins during the assembly of the head of bacteriophage T4. Nature 227, (5259): 680-685 
Misra, R. V., Roy, R. H., and Hiraoka (2003). On farm composting method. FAO, Rome.

Narasimha, G., Sridei, A., Golla, R., and Bontha, R. R (2016).

Purification and characterization of $\beta$-glucosidase from $A$. niger. International Journal of Food Properties, 19:(3) 652-661.

Obilie, E.M., Tano-Debrah, K., and Amoa-Awua, W.K. (2004). Souring and breakdown of cyanogenic glucosides during the processing of cassava into akyeke. International Journal of Food Microbiology, 93(1): 115-121.

Saleem, M., Samiullah, T. R., Bakhsh, A., Rao, A. Q., and Naz, M. (2009). Isolation, Purification and characterization of extracellular $\beta$-glucosidases from Bacillus sp.; Advances in Environmental Biology, 3(3): 269-277.

Saloheimo, M., Nakari-Setala, T., Tenkanen, M.,and Penttila, M. (1997). cDNA cloning of a Trichoderma reesei cellulase and demonstration of endoglucanase activity by expression in yeast. European Journal of Biochemistry, 249: 584-591.

Sorensen, A., Lubeck, M., Lubeck, P.S., and Ahring, B.K. (2013). Fungal betaglucosidases: a bottleneck in industrial use of Lignocellulosic materials. Biomolecules, 3(3):612 -631.

Swangkeaw, J., Vichitphan, S., Butzke, C.E., and Vichitphan , K.(2009). The characterisation of a novel Pichia anomala $\beta$ glucosidase with potentially aroma-enhancing capabilities in wine Annals of Microbiology, 59 (2): 335-343.

Tomaz, T. and Roche, A. (2002). Hydrophobic interaction, Chromatography of Trichoderma reesei cellulase on Polypropylene glycol-Sepharose. Separation Science Technology, 37: 1-11.
Tsao, G. T., Xia, L., Cad, N., and Gong,C.S. (2000). Solid state fermentation with Aspergilus niger for cellobiase production. Applied Biochemistry and Biotechnology, 84-86:743-747.

Viniegra-Gonzalez, G., and Favela-Torres, E (2006). Why solid-state fermentation seems to be resistant to catabolite repression. Food Technology and Biotechnology, 44 (3): 397 406.

Zhang, C., Li, D., Yu, H., Zhang, B., Jin, F. (2007). Purification and characterization of Peceid $\beta$-glucosidase from Aspergillius orgzae. Press Biochemistry, 42:83-88. 